\title{
LIFE AFTER DEATH-THE HUMAN ORGANS TRANSPLANTATION ACT A REVIEW
}

\author{
Jyoti C. Mane \\ Associate Professor, Department Of Agadtantra \\ Dr. J. J. Magdum Ayurved Medical College, Jaysingpur \\ Dist. Kolapur, Maharashtra, India \\ *Author Correspondence: Mail ID- jyoti.c.mane@gmail.com; Mobile No. 9422750347
}

\begin{abstract}
: -
We all have been hearing, reading and seeing many issues regarding organ transplantation, but many people are not aware and serious regarding Human organ transplant. Many patients struggle for life after failure of functioning of some major organs. A patient with a case of rena failure can survive for some period wit the help of advance technique Viz. Dialysis, but patients with failure of function of liver or Heart etc. have no substitute for Human Organ Transplant. It is a small effort to encourage and create awareness in people to promote organ transplant. In last 10 years people are much aware regarding organ donation and organ transplant. The person certified as brain dead can only donate his healthy organs to a needy and increase his life span ${ }^{[2]}$. In India we can see advancement in the field of transplantation. The law regarding Human Organ Transplant was passed in the year 1994 it came into force in $1995^{[1]}$ This law includes Regulations regarding removal, preservation and transplantation of organ for treatment purpose and prevention of commercialization of human organs ${ }^{[1]}$.
\end{abstract}

KEY WORDS- Human Organ transplant, Human organ donation, Brain death and
The Transplantation of Human Organs Act 1994.

\section{INTRODUCTION-}

Amongst all the advancement in medical science most notable and life aving potential is Human Organ ransplant. There are many controversial issues Viz. medico-legal, religious and ethical in concerned with organ transplant. There are many incidences in press regarding robbery of Kidney of the patient on the operation table, kidnapping people for the same. ${ }^{[1]}$ Looking at all such incidences the government of India decided to frame the law concerned to Human Organ Transplant. The law also includes the list of organs that can be donated the organs enlisted are The Kidneys, heart,lungs,liver, pancreas, eyes(cornea),eardrum, and ear bones. The law defines the limits of live transplants into three categories- Blood Relations, spouses, donation out of affection. All the applications received are scrutinized by the state authorized committee to avoid unrelated transplant. ${ }^{[1]}$ Transplants are to be conducted in the registered hospitals only and the state authorized committee monitors its functioning. The whole organs which cannot replicate cannot be removed 
from the body in live state and transplanted to the recipient. ${ }^{[2]}$

The Human organs are to be removed after brain stem death certification. The brain stem death certification is not done by any doctor in the team of transplant team or by the surgeon performing the transplant ${ }^{[2]}$ the brain stem death is to be certified by the doctor in-charge of the hospital where the brainstem death has taken place, or any doctor nominated by the hospital, or any neurophysician/neurosurgeon nominated by the hospital or by the doctor who was treating the patient. ${ }^{[2]}$ After removal of the organs/tissues form the body the consent of the relative is taken before donation to the recipient. ${ }^{[2]}$

\section{AIMS AND OBJECTIVES-}

- To create awareness of organ donation in people.

- To study and summaries the law related to organ donation transplant.

- To clear some unknown facts related to organ donation and transplants

\section{MATERIALS AND METHODS-}

Before carrying out the main procedure of transplant the subject is to be certified as brain death. This is the condition where irreversible cessation of all function of the entire along with the brainstem is noticed. The international standard for brain stem death is considered to include the whole brain death i.e. A situation where the higher brain (thought and consciousness regulating part of brain), the cerebellum or midbrain and the brain stem have no response to any electric activity for the time period. ${ }^{[3]}$ When a person is not responding to any stimulus and is able to maintain respiration and circulation then he cannot be certified as brain stem dead. Cadaver transplantation is term used when organs to be transplanted is collected from a person who has been certified as brain dead. ${ }^{[3]}$ looking at all these incidences The Transplantation of Human Organs and Tissues Act 1994 the Brain death is to be certified by the above said authorities only.

The brain stem death is declared after looking at the brain stem reflexes viz. constriction of pupils in light, blinking due to corneal stimulation, grimace due to pressure on medial tips of eyebrows, eye ball movements to flushing of eyes with water and cough reflex due to irritation to pharyngeal wall. If these reflexes are found to be absent when checked twice at six hourly intervals then the person is subjected to Apnoea test(test to check respiration effort if ventilator is disconnected) if the test is negative i.e.no respiration then the last confirmation is done by EEG recording for 30 minutes

Harvard's exclusion criteria for tansplation:-

1. If the cause of deep coma is drug over dose hypothermia or due to metabolic disorder.

2. If the cause of coma is irreversible structural damage of brain. ${ }^{[1]}$

Transplants are of five types ${ }^{[2]}$

1) Autograft / Autotransplant/ homologous- Transplantation of tissue of same person from one part to another.

2) Allograft/ allogenic/HomograftTransplantation of tissue from one person to other person of same species.

3) Isograft- Transplantation of tissue in identical recipient like in identical twins.

4) Xenograft- Transplantation of tissue from one species to other.

5) Split transplant- Transplantation of organ of $\mathrm{o}$ donor between two recipients. $^{[2]}$ 


\section{Guidelines on cadaver donor transplant}

\section{[3]}

1. The person willing to donate organs after death should inform the same to the person very near to him/her. They should also know about the people opposing this decision so that the wish of the person is respected after death. This can be recorded in written form and this "Living Will" is in practice in many countries.

2. In case of absence of such documentation the person in lawful possession of the body will take a decision after consulting the family members.

3. The medical team has to make use of the body for which the consent is given.

4. No financial deal should be made during such procedure.

5. The secrecy of donation must be maintained strictly on both sides to prevent any form of exploitation.

\section{Guidelines on recipient of transplant ${ }^{[3]}$}

1. The organ donors are urgently searched, as the demand for organs is more due to failure of vital organs and costlier maintenance techniques till availability.

2. The patient may consent to the procedure putting themselves at high risk. So the committee should go through the research protocol properly so that evaluation will be impartial scientifically and ethically.

3. The transplant team should include highly technical expertise.

4. The transplant centers should be well equipped with all amenities necessary for data management, tissue collection, storage and monitoring the procedure.

5. The patient should not be pressurized to take the treatment related to organ transplant if he/she wants to quit at any moment.

\section{Guideline on live Donor transplant ${ }^{[3]}$}

1. In case of live donor the denotation of the tissues which can regenerate or paired organs is permitted so that the donation should not disturb his/her physiological function or cause disfigurement.

2. Every procedure should be handled with great responsibility after careful assessment to improve success rate of transplant.

3. Priority of interest should be given to the donor than recipient of transplant.

4. The consent of the donor is first taken prior to the procedure after explaining the risk factors in his/her understanding language.

5. The donor should be legally eligible to give consent. Children's and mentally ill people are not eligible to give consent and should not be included as donors.

6. It is complete responsibility of the person handling the case to give detail information about the procedure till he/she understands.

7. The procedure should be done in good faith to succeed, this procedure is carried out if there is no alternative method for transplant.

8. The procedure should be well planned and carried out to prevent unnecessary complications to donor as well as recipient, proper post transplant care must be taken and sufficient number of trained staff must be available to manage the possible discomfort to the recipient.

9. The donor should be free to withdraw from the procedure before its beginning, after knowing the procedure and cannot be forced to do so without his/her consent. ${ }^{[3]}$ 
There is increased success rate in transplant surgeries in recent years due to maintenance of cadaver like living donor through beating heart donor. This is carried out using sophisticated equipments helpful in keeping functioning of respiration and circulation after being certified dead. This in turn maintains the oxygen level in the sensitive area of brain i.e. cortex of brain, thalamus and brainstem. The brain stem regulates the basic function of the body like respiration and vasomotor centers $^{[1]}$

\begin{tabular}{|l|l|l|l|}
\hline $\begin{array}{l}\text { Sr. } \\
\text { no. }\end{array}$ & $\begin{array}{l}\text { Name of } \\
\text { the organ }^{\text {Liver }}\end{array}$ & $\begin{array}{l}\text { Time of } \\
\text { retrieval }^{[4]}\end{array}$ & $\begin{array}{l}\text { Time of } \\
\text { storage }^{[2]}\end{array}$ \\
\hline 1. & minutes & 12 hours \\
\hline 2 & Pancrease & $\begin{array}{l}15 \\
\text { minutes }\end{array}$ & 12 hours \\
\hline 3 & Kidney & $\begin{array}{l}45 \\
\text { minutes }\end{array}$ & 24 hours \\
\hline 4 & Heart & 1 hour & 3 hours \\
\hline 5 & $\begin{array}{l}\text { Heart } \\
\text { valve }\end{array}$ & 10 years \\
\hline 6 & Cornea & 6 hours & 2 weeks \\
\hline 7 & $\begin{array}{l}\text { Bone } \\
\text { marrow }\end{array}$ & 5 years \\
\hline 8 & Skin & 3 hours & 5 years \\
\hline 9 & Middle ear & & 5 years \\
\hline
\end{tabular}

\section{DISCUSSION-}

According to the study conducted by the Indian medical association, every year approximately 2 lacks people are in need of kidney transplant where as kidney donation is comparatively less. In India cadaver transplant is very low as compared to Spain where organ donation is very highIn India the organ donation rate is 0.05/million and 50 cadaver donation per year. Liver transplant was documented highest in tally.

This low awareness leads to commercial dealing in human organs, scandals by medical practioners. The medical faculties say that the rules related to organ transplant are very hard to follow. Like section saying that close relative can donate kidney is to be widened to non relative can donate. ${ }^{[1]}$ There are some incidences recorded like marrying a woman for the sake of kidney and then divorcing her for getting approval by the committee. People go for organ donation due to poverty and loans this was result of survey conducted at Chennai. The amount received by selling the organs is used to clear the loans, food and clothing's. Again the family income decreases due to nephrectomy and in turn the poverty persists as it is.

Punishment for unauthorized removal of human organs:-

1. The doctor involved in unauthorized organ removal is punishable fine up to Rs. 10,000/and imprisonment for $5 \mathrm{yrs}$

2. The name of the doctor involved in the offence is being removed from the register of state medical council for the period of 2 years for the first offence and if offence is repeated then it is permanently removed.

3. Any person involved in commercial dealing of human organs then he is imprisoned for the period of 2 years to 7 years with penalty of Rs 10,000-20,000

\section{CONCLUSION-}


This article is to encourage the people for organ donation. It is said that in some community before disposal of the dead body the cadaver is taken to the hospital and given a written consent to remove the necessary organs that are in well condition and transplant to the needy person. The intension behind this procedure is let the person be selfish or a criminal during his life, his sins are reduced by giving life to a needy by donating organs to the same. It is said that at least five people can be transplanted by the organs obtained from a single cadaver.

\section{REFERENCE:-}

1. Text book of Forensic Medicine and toxicology -Dr.V.V. Pillay- $18^{\text {th }}$ edition-Medical law and ethics page no. 46

2. Review of Forensic medicine and toxicology-Dr. Gautam Biswas- $3^{\text {rd }}$ edition-Acts related to Medical practices.-page no. 30-31

3. A text book of Medical Jurisprudence and toxicologyJaising P Modi- $25^{\text {th }}$ edition-Brain stem Death and transplant of human organs Act-page no. 183198

4. Text book of Medical Jurisprudence and toxicology- Prof C. K. Parik- $7^{\text {th }}$ edition- Medico legal aspect of death investigationpage no. 138

Cite article:

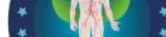

LIFE AFTER DEATH-THE HUMAN ORGANS TRANSPLANTATION ACT A REVIEW Jyoti Chandrashekhar Mane

Ayurlog: National Journal of Research in Ayurved Science- 2018; (6)(6): 1-5 